
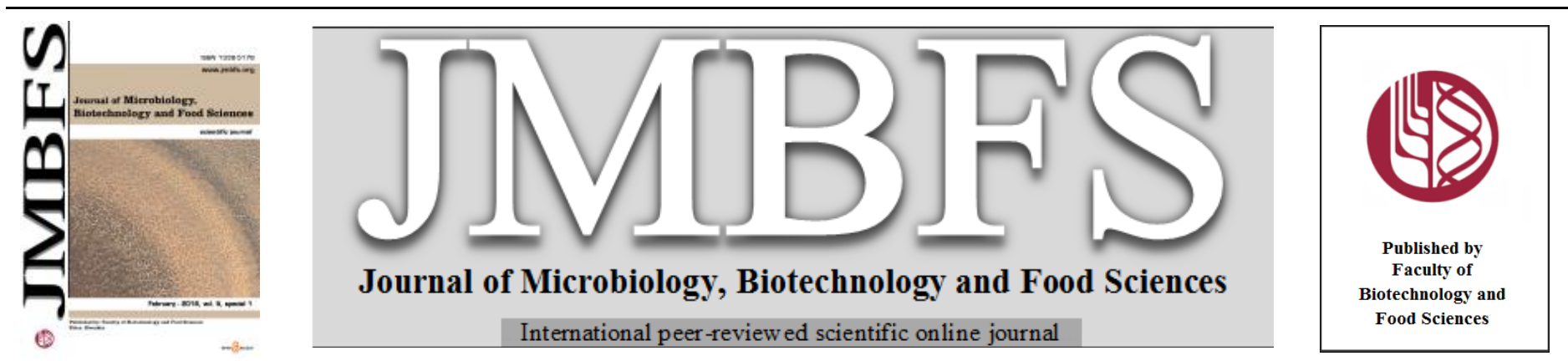

\title{
TOTAL CHOLESTEROL AND CORTICOSTERONE CONCENTRATION RELATIONSHIP IN BLOOD PLASMA OF LAYING HENS
}

\author{
Aleš Pavlikk*1, Petr Sláma ${ }^{l}$, Lenka Mazalovál ${ }^{l}$ Eliška Kabourkovál
}

Address(es): Ing. Aleš Pavlík, Ph.D.

${ }^{1}$ Mendel University in Brno, Faculty of Agronomy, Department of Animal Morphology, Physiology and Genetics, Zemědělská 1, 61300 Brno, Czech Republic, phone number: +420545133148 .

*Corresponding author: pavlik@mendelu.cz

doi: $10.15414 / j m b f s .2016 .5 . s p e c i a l 1.17-19$

\section{ARTICLE INFO}

Received 11. 12. 2015

Revised 20.1.2016

Accepted 22. 1.2016

Published 8. 2. 2016

Regular article

OPEN $\bigcirc$ ACCESS

\begin{abstract}
The aim of this study was to analyze the effect of laying hens housing condition on the plasma total cholesterol and corticosterone concentrations relationship at the beginning, middle and end of the laying period. The experiments were performed in ISA BROWN egg production pullets, kept in a poultry house for rearing with deep litter technology. Blood samples $(2 \mathrm{ml})$ of all hens in experimental groups were collected from brachial vein at 22, 28, 35, 41, 47, 52, 58 and 66 weeks of age. Plasma corticosterone levels were analyzed by radioimmunoassay and plasma total cholesterol by spectrometry. One-way ANOVA showed significant differences in cholesterol as well as corticosterone levels of blood plasma of laying hens during the experimental period. A very low relationship was found between individual total plasma cholesterol and corticosterone concentrations during the monitored period.
\end{abstract}

Keywords: Laying hens, furnished cage technology, blood plasma, cholesterol, corticosterone

\section{INTRODUCTION}

Cholesterol is a lipid with a unique structure consisting of four linked hydrocarbon rings forming the bulky steroid structure. Its levels in tissues reflect a balance among dietary uptake, endogenous de novo synthesis, efflux, and utilization to bile acids (Faust and Kovacs, 2014). With respect to cholesterol uptake, the low density lipoprotein receptors are well-known for their important roles in regulating plasma and intracellular cholesterol homeostasis (Soto-Acosta et al., 2013), they are primarily modulated by intracellular cholesterol levels (Liu et al., 2012). As an essential component of cell structure and the precursor of steroid hormones, the amount of cholesterol in chicken muscle will affect avian well-being, and may ultimately influence human health through dietary intake. Glucocorticoids are the counter regulatory hormones with broad effects on carbohydrate, lipid and protein metabolism (Bamberger et al., 1996). Glucocorticoids participate in the control of whole body homeostasis and the response of the organism to stress by stimulating there lease of energy stores via promoting glucose mobilization and lipolysis (Harvey et al., 1986). Glucocorticoid treatment is associated with increased levels of circulating free fatty acids in humans (Macfarlane et al., 2008) and rodents (Novelli et al., 2008). In birds it has been reported that corticosterone and insulin interact to regulate triglyceride and cholesterol levels during stress (Remage-Healey and Romero, 2001). Glucocorticoids, especially corticosterone, are involved in the control of appetite in poultry (Yuan et al., 2008). El-Letheye et al. (2001) have shown that corticosterone can increase feed intake of chickens. Furthermore, there are reports of augmentation in plasma corticosterone after $24 \mathrm{~h}$ of feed deprivation in immature chickens (Geris et al., 1999). Hyperlipidemia and metabolic abnormalities caused by endogenous glucocorticoid excess have been well documented in mammals and birds. In mammals, increased circulating glucocorticoids together with the altered insulin sensitivity are suggested to be responsible for enhanced visceral fat deposition and hyperlipidemia (Geraert $\boldsymbol{e} t$ al., 1996). Chronic corticosterone administration did not change plasma lipid profile, except for a moderate increase of high density lipoprotein cholesterol levels in broiler chickens (Wang et al., 2013). Chronic endogenous glucocorticoid excess in mammals is associated with metabolic dysfunction and dyslipidemia that are characterized by increased plasma triglyceride and total cholesterol levels (Duan et al., 2014).

The objective of our study was to analyze the effect of laying hens housing condition on the plasma total cholesterol and corticosterone concentrations relationship at the beginning, middle and end of the laying period.

\section{MATERIAL AND METHODS}

\section{Animals and experimental conditions}

The experiments were performed in ISA BROWN egg production pullets, kept in a poultry house for rearing with deep litter technology. The available area, complete feeding mixture, light-dark (L:D) cycle, temperature of housing, relative humidity of air changed according to technological instructions for ISA BROWN pullets. During rearing period standard vaccinations were provided. At the age of 15 weeks, they were transferred into o furnished cage technology according to Council Directive 74/99/EC - three-tier, total area $945 \mathrm{~cm}^{2} /$ bird (8 birds kept on an area of $7560 \mathrm{~cm}^{2}-180 \times 42 \times 45 \mathrm{~cm}$ ), available area $643 \mathrm{~cm}^{2} /$ bird, 6 nipple drinkers, belt feeder $20 \mathrm{~cm} /$ bird, nest $(30 \times 35 \times 45 \mathrm{~cm})$, perching area 15 $\mathrm{cm} /$ bird, devices for dustbathing and scratching, device for claw shortening. Experimental group consisting of 12 birds was established with the mean body weight of $1300 \pm 50 \mathrm{~g}$. Throughout the study, the hens were fed with balanced layer feeds that contained 875 g. kg ${ }^{-1}$ dry matter, energy content $\mathrm{ME}_{\mathrm{N}} 11.1 \mathrm{MJ} . \mathrm{kg}$ 1 , content of nitrogen substances $170.7 \mathrm{~g} \cdot \mathrm{kg}^{-1}$, Ca $35.9 \mathrm{~g} \cdot \mathrm{kg}^{-1}$ and P $6.3 \mathrm{~g}^{\mathrm{kg}} \mathrm{kg}^{-1}$. A constant light-dark (L:D) cycle (15:9, switching on at $4.00 \mathrm{AM}$, switching off at $19.00 \mathrm{PM}$ ) was maintained in all three technologies as recommended in technological instructions for ISA BROWN pullets. The temperature of housing was in the range from 18 to $20^{\circ} \mathrm{C}$, relative humidity of air was ranging from 65 to $70 \%$. No red mite and other parasite or viral infection was presented during experimental period.

\section{Blood sampling}

Blood samples $(2 \mathrm{ml})$ of all hens in experimental groups were collected from brachial vein at $22,28,35,41,47,52,58$ and 66 weeks of age, always between 7.00 and $8.30 \mathrm{am}$. EDTA was used as anticoagulant. Blood samples were centrifuged $\left(20 \mathrm{~min}, 4^{\circ} \mathrm{C}, 2500 \mathrm{~g}\right)$ and the separated plasma was stored at $-20^{\circ} \mathrm{C}$ until analyzed. Blood sampling was performed randomly in hens kept in standard, enriched and deep litter technology. Utmost care was given to keep the time within 2 minutes between catch and conclusion of blood sampling because this small gap is known to have little or no effect on corticosterone secretion in layers (Craig and Craig, 1985). 


\section{Plasma corticosterone and cholesterol analysis}

Plasma corticosterone levels were analyzed by radioimmunoassay following dichloromethane (Merck, Darmstadt, Germany) extraction of the steroids from $100 \mu \mathrm{l}$ aliquots of plasma and using ${ }^{3} \mathrm{H}$-corticosterone (Amersham, UK) as described previously (Jezova et al., 1994). Radioactivity of free corticosterone was counted using a liquid scintillation counter (Beckman LS-6500; BeckmanCoulter, USA). Corticosterone (Sigma, Steinheim, Germany, minimal purity $92 \%, \mathrm{C} 2505)$ was used as a standard. Standard curve was performed using 31.5 $62.5,125,250,500,1000,2000,4000,8000 \mathrm{pg}$ of corticosterone per tube. The sensitivity of corticosterone assay was $0.5 \mathrm{ng} \cdot \mathrm{ml}^{-1}$ plasma. The intra- and interassay coefficients of variations were 6 and $8 \%$, respectively. All hormone measurements were performed in duplicates. Quality of the assay was controlled by repeated analysis of corticosterone in plasma pools with low and high corticosterone concentrations. Measurements of corticosterone in the same control samples were included in all assays performed. Specific antibodies were kindly provided by Prof. C. Oliver, Laboratory of Experimental Neuroendocrinology (Marseille, France). The antibody cross-reacted 100\% with cortisone and cortisol, 24\% with 11-deoxycorticosterone, $22 \%$ with aldosterone, $16 \%$ with 17-OH-progesterone, $4 \%$ with androstendione, progesterone and testosterone and less than $0.1 \%$ with estradiol and estrone.

Total cholesterol concentrations in blood plasma were analysed by spectrometry on the KONELAB T20xt automatic analyser (Thermo Fisher Scientific, Finland) and currently available commercial kits (Biovendor-Laboratorni medicina, Czech Republic).

\section{Statistical analysis}

Statistical analysis of the obtained data was performed using the STATISTICA 8.0 programme by single-factor analysis of variance for factor animal age ANOVA was followed by post-hoc Fischer LSD test for pair-wise comparisons, when appropriate. Evaluation of the interdependence between the cholesterol and corticosterone concentrations was conducted using a correlation coefficient at the level of probability $(\mathrm{P}<0.01)$.

\section{RESULTS AND DISCUSSION}

One-way ANOVA showed significant differences in blood plasma cholestero levels of laying hens during the experimental period $F(7,88)=3.5808$, $\mathrm{p}=0.00195)$. The Fisher post hoc testing showed a significant increase $(p<0.01)$ of the cholesterol level at the age of 28 weeks $\left(3.81 \pm 0.340\right.$ mmol. $\left.\mathrm{l}^{-1}\right)$. Subsequently the cholesterol concentrations changed during the experimental period without any significance (figure 1). The highest concentration of cholesterol was recorded in week $47\left(4.68 \pm 0.918 \mathrm{mmol} . \mathrm{l}^{-1}\right)$. As with cholesterol, the corticosterone concentrations changed during determined period (figure 1). The age of hens significantly influenced the level of plasma corticosterone, as shown by one-way ANOVA $(\mathrm{F}(7,88)=7.2110, \mathrm{p}=0.00035)$. The Fisher post hoc testing showed a significant increase $(p<0.01)$ of the corticosterone level at the age of 52 weeks $\left(1.38 \pm 0.067\right.$ ng.ml $\left.{ }^{-1}\right)$. A similar concentration was found at the age of 58 weeks. A significant decrease $(p<0.01)$ was recorded at the end of the experimental period $\left(0.98 \pm 0.078 \mathrm{ng} \cdot \mathrm{ml}^{-1}\right)$. A very low relationship was found between the individual total plasma cholesterol and corticosterone concentrations during the monitored period, with a correlation coefficient $\mathrm{r}=0.178((p<0.05)$.

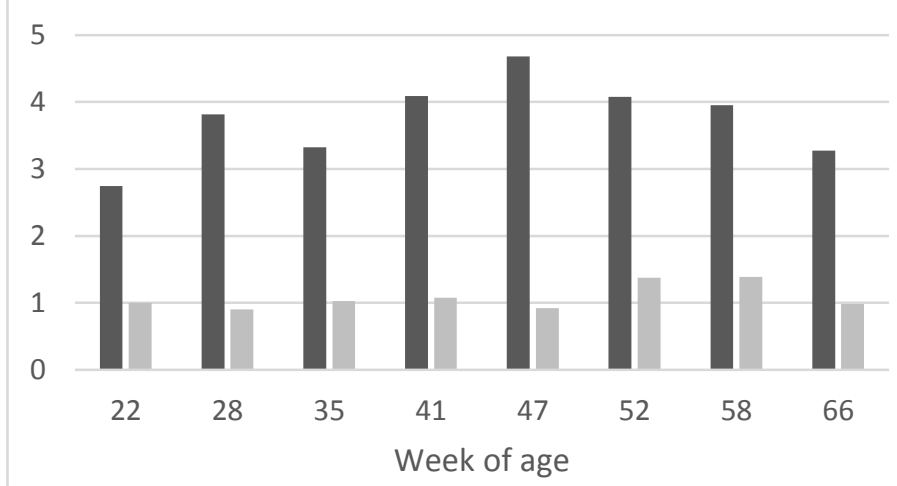

- Total cholesterol $\quad$ Corticosterone

Figure 1 Total cholesterol and corticosterone concentrations in blood plasma of laying hens during experimental period. Total cholesterol is presented in mmol.1 ${ }^{1}$, corticosterone in ng. $\mathrm{ml}^{-1}$. Data in columns represent mean.

In our experiment, plasma corticosterone levels increased with age, showing some variation in the middle of the trial and a slight decrease at the week 58 up to week 66 of age. Changes in corticosterone levels in the laying period have been attributed to the seasonal effects during breeding (Koelkebeck et al., 1984) Also, animals are exposed to many external factors. Factors that may induce stress responses include stocking density, temperature, transport, feed restriction, feed contamination, fear and diseases (Nicol et al., 2006), which can activate the hypothalamic-pituitary-adrenal axis to enhance the release of glucocorticoids from the adrenal gland (Carsia and Harvey, 2000). Elevated release of corticosterone from the adrenal cortex in response to stressful stimuli has been proposed to promote gluconeogenesis and lipolysis to break down fat tissues to provide the bird with more energy (Scanes, 2009). In our experiment, the concentration of total cholesterol in the blood plasma of laying hens increased in all groups from week 22 to 47 of age, with a subsequent decrease to the end of the monitored period. Intracellular cholesterol content depends on three major factors: cholesterol uptake into cells, de novo cholesterol synthesis within cells, and efflux of cholesterol out of cells (Feeney et al., 2013). With respect to de novo cholesterol synthesis, multiple mechanisms for the feedback control of cholesterol biosynthesis converge at the rate-limiting enzyme 3-hydroxy-3methylglutaryl coenzyme A reductase (HMGCR) (Garevik et al., 2012) Glucocorticoids elevate the HMGCR activity in cells (Cavenee and Melnykovych, 1979). The chicken HMGCR gene is present in many tissues, including the brain, liver, intestine and skeletal muscle (Burtea et al., 1991). The liver is a key organ involved in the control of plasma cholesterol, which is largely determined by the rate of removal of low density lipoproteins from the circulation via hepatic low density lipoprotein receptor (Myant et al., 1991). The number of hepatic low density lipoprotein receptors directly governs plasma low density lipoprotein cholesterol (Rudling et al., 2002). Glucocorticoids stimulates a concentration- and time-dependent increase of low density lipoprotein receptor biosynthesis in cultured fibroblasts (Filipovic and Buddecke, 1985). Receptormediated cholesterol uptake is suggested to play a role in maintaining the intracellular free cholesterol pool. Duan et al. (2014) found that muscular low density lipoprotein receptors levels in corticosterone treated chickens were significantly increased compared with controls. High glucocorticoids levels enhance lipid accumulation into macrophages cultured in vitro by increased cholesterol ester synthesis and decreased cholesterol ester breakdown without altering cholesterol influx or efflux (Cheng et al., 1995). Duan et al. (2014) recorded, that chronic corticosterone administration induces cholesterol and triglyceride accumulation in chicken muscle by upregulating their intracellular synthesis and uptake. Yeon-Hwa Kim et al. (2015) determined significantly higher plasma corticosterone concentrations in corticosterone-treated group compared with control. Increased concentrations were found also for cholesterol.

\section{CONCLUSION}

In this study we analyzed the effect of laying hens housing condition on the plasma total cholesterol and corticosterone concentrations at the beginning, middle and end of the laying period. In conclusion, our experiment revealed no relationship between the blood plasma corticosterone and cholesterol concentrations.

Acknowledgments: This study was supported by the Ministry of Agriculture, Czech Republic, Grant No. QC1128.

\section{REFERENCES}

Bamberger, C.M., Schulte, H.M., Chrousos, G.P. (1996). Molecular determinants of glucocorticoid receptor function and tissue sensitivity to glucocorticoids. Endocrine Reviews 17, 245-261. http://dx.doi.org/10.1210/er.17.3.245

Burtea, C., Murgiuc, C., David, A., Dragomir, C.T. (1991). Influence of sex and glucocorticoid hormones on $3 \mathrm{H}$ cholesterol uptake in the aortic wall and $3 \mathrm{H}$ adrenaline in the brain. Endocrinologie, 29, 137-145.

Carsia, R.V., Harvey, S. (2000). Chapter 19. Adrenals In: Sturkie's Avian Physiology, Fifth Edn, (Ed. G. C. Whittow). Academic Press, San Diego, CA, USA. pp. 489-537.

Cavenee, W.K., Melnykovych, G. (1979). Elevation of HeLa cell 3-hydroxy-3methylglutaryl coenzyme A reductase activity by glucocorticoids: possible relationship to the cell cycle. Journal of Cellular Physiolpgy, 98, 199-211. http://dy.doi.org/10.1002/jcp.1040980122

Duan, Y., Fu, W., Wang, S., Ni, Y., Zhao, R. (2014). Cholesterol deregulation induced by chronic corticosterone (CORT) stress in pectoralis major of bloiler chickens. Comparative Biochemistry and Physilology, Part A, 176, 59-64 http://dx.doi.org/10.1016/j.cbpa.2014.07.010

El-Lethey, H., Jungi, T.W., Huber-Eicher, B. (2001). Effects of feeding corticosterone and housing conditions on feather pecking in laying hens (Gallus gallus domesticus). Physiology and Behaviour, 73, 243-251. http://dx.doi.org/10.1016/S0031-9384(01)00475-9

Faust, P.L., Kovacs, W.J. (2014). Cholesterol biosynthesis and ER stress in peroxisome deficiency. Biochimie 98C, 75-85 http://dx.doi.org/10.1016/j.biochi.2013.10.019

Feeney, E.R., McAuley, N., O'Halloran, J.A., Rock, C., Low, J., Satchell, C.S. Lambert, J.S., Sheehan, G.J., Mallon, P.W. (2013). The expression of cholesterol metabolism genes in monocytes from HIV-infected subjects suggests intracellular 
cholesterol accumulation. Journal of Infectious Diseases, 207, 628-637. http://dx.doi.org/10.1093/infdis/jis723

Filipovic, I., Buddecke, E. (1985). Glucocorticoid-stimulated biosynthesis of low density lipoprotein receptor in cultured fibroblasts. Journal of Clinical Chemistry and Clinnical Biochemistry, 23, 331-336.

Garevik, N., Skogastierna, C., Rane, A., Ekstrom, L. (2012). Single dose testosterone increases total cholesterol levels and induces the expression of HMG CoA reductase. Substance Abuse Treatment, Prevention, Policy 7, 12 http://dx.doi.org/10.1186/1747-597X-7-12

Geraert, P.A., Padilha, J.C., Guillaumin, S. (1996). Metabolic and endocrine changes induced by chronic heat exposure in broiler chickens: growth performance, body composition and energy retention. British Journal of Nutrition, 75, 195-204. http://dx.doi.org/10.1079/BJN19960124

Geris, K.L., Berghman, L.R., Kuhn, E.R., Darras, V.M. (1999). The drop in plasma thyrotropin concentrations in fasted chickens is caused by an action at the level of the hypothalamus: role of corticosterone. Domestic Animal Endocrinology, 16, 231-237. http://dx.doi.org/10.1016/S0739-7240(99)00016-8

Harvey, S., Scanes, C.G., Brown, K.I. (1986). Adrenals, Avian physiology4th ed. SpringerVerlag, New York, NY.

Cheng, W., Kvilekval, K.V., Abumrad, N.A. (1995). Dexamethasone enhances accumulation of cholesteryl esters by human macrophages. American Journal of Physiology, 269, E642-E648.

Jezova, D., Guillaume, V., Jurankova, E., Carayon, P. and Oliver, C. (1994): Studies of the physiological role of ANF in ACTH regulation. Endocrine Regulations, 28: 163-169.

Kim, Y., Kim, J., Yoon, H., Yang-Ho Choi, Y. (2015)- Effects of Dietary Corticosterone on Yolk Colors and Eggshell Quality in Laying Hens. Asian Australian Journal of Animal Science, 28(6), 840-846. http://dx.doi.org/10.5713/ajas.14.0849

Koelkebeck, K.W., Cain. J.R. (1984). Performance, behavior, plasma corticosterone, and economic returns of laying hens in several management alternatives. Poultry Science, 63, 2123-2131.

Liu, J., Ma, K.L., Gao, M., Wang, C.X., Ni, J., Zhang, Y., Zhang, X.L., Liu, H., Wang, Y.L., Liu, B.C. (2012). Inflammation disrupts the LDL receptor pathway and accelerates the progression of vascular calcification in ESRD patients. PLoS One 7, http://dx.doi.org/10.1371/journal.pone.0047217

Macfarlane, D.P., Forbes, S., Walker, B.R. (2008) Glucocorticoids and fatty acid metabolism in humans: fuelling fat redistribution in the metabolic syndrome. Journal of Endocrinology, 197, 189-204. http://dx.doi.org/10.1677/JOE-08-0054 Myant, N.B., Gallagher, J.J., Knight, B.L., McCarthy, S.N., Frostegard, J. Nilsson, J., Hamsten, A., Talmud, P., Humphries, S.E. (1991). Clinical signs of familial hypercholesterolemia in patients with familial defective apolipoprotein B-100 and normal low density lipoprotein receptor function. Arteriosclerosis, Thrombosis and Vascular Biology, 11, 691-703.

Nicol, C.J., Brown, S.N., Glen, E., Pope, S.J., Short, F.J., Warris, P.D., Zimmerman, P.H. \& Wilkins, L.J. (2006) Effects of stocking density, flock size and management on the welfare of laying hens in single-tier aviaries. British Poultry Science, 47, 135-146. http://dx.doi.org/10.1080/00071660600610609

Novelli, M., Pocai, A., Chiellini, C., Maffei, M., Masiello, P. (2008). Free fatty acids as mediators of adaptive compensatory responses to insulin resistance in dexamethasone-treated rats. Diabetes Metabolism Research and Reviews, 24, 155-164. http://dx.doi.org/10.1002/dmrr.785

Remage-Healey, L., Romero, L.M. (2001). Corticosterone and insulin interact to regulate glucose and triglyceride levels during stress in a bird. American Journal of Physiology, Regulative and Comparative Physiology, 281, 994-1003.

Rudling, M., Angelin, B., Stahle, L., Reihner, E., Sahlin, S., Olivecrona, H., Bjorkhem, I., Einarsson, C. (2002). Regulation of hepatic low-density lipoprotein receptor, 3-hydroxy-3-methylglutaryl coenzyme A reductase, and cholesterol 7alpha-hydroxylase mRNAs in human liver. Journal of Clinical Endocrinology and Metabolism, 87, 4307-4313. http://dx.doi.org/10.1210/jc.2002-012041

Scanes, C.G. (2009). Perspectives on the endocrinology of poultry growth and metabolism. General and Comparative Endocrinololy, 163, 24-32. http://dx.doi.org/10.1016/j.ygcen.2009.04.013

Soto-Acosta, R., Mosso, C., Cervantes-Salazar, M., Puerta-Guardo, H., Medina, F., Favari, L., Ludert, J.E., del Angel, R.M. (2013). The increase in cholesterol levels at early stages after dengue virus infection correlates with an augment in LDL particle uptake and HMG-CoA reductase activity. Virology, 442, 132-147. http://dx.doi.org/10.1016/j.virol.2013.04.003

Wang, S., Ni, Y., Guo, F., Fu, W., Grossmann, R., Zhao, R. (2013). Effect of corticosterone on growth and welfare of broiler chickens showing long or short tonic immobility. Comparative Biochemistry and Physiology A Molecular and $\begin{array}{llll}\text { Integrative } & \text { Physiology, } & \text { 537-543. }\end{array}$ http://dx.doi.org/10.1016/j.cbpa.2012.12.014

Yuan, L., Lin, H., Jiang, K.J., Jiao, H.C., Song, Z.G. (2008). Corticosterone administration and high-energy feed results in enhanced fat accumulation and insulin resistance in broiler chickens. British Poultry Science, 49, 487-495. http://dx.doi.org/10.1080/00071660802251731 